\title{
Phenotypic characterization of sheep breeds in Gamogofa zone
}

\author{
Fsahatsion Hailemariam*, Dawit Gebremicheal and Hagos Hadgu
}

\begin{abstract}
Background: Information on the morphometric character of indigenous sheep population in their habitat is prerequisite to set up the breed improvement under the farmer level in Ethiopia. Still, there is a long way to characterize, identify and document the existing indigenous sheep type. The study was conducted in Gamogofa zone of Southern Ethiopian with the objective of describing the morphological characterization of the indigenous sheep breed.

Methods: Purposive sampling techniques were employed to select target farmers. Qualitative, body weight and body measurement were taken from 736 sheep. All the collected data were analyzed using Generalized Linear Model procedure of the statistical analysis system (release 9.1, 2003).

Results: Plain black (34\%) and red (19.6\%) are the dominant color types with long thin tail (88.2\%) in both ewe and ram sheep. Almost $99.3 \%$ of ewe's and $100 \%$ of rams had no wattle. The majority (90.4\%) of the sheep had a straight tail form at the tip, straight head profiles (88.7\%) and also horizontal ear forms (51.2). Agroecology, sex, and age had a significant effect on body weight and linear body measurements. The mean body weight, whiter height, body length, chest girth, shoulder width, cannon bone width, tail length, and tail circumference for ram and ewe sheep were $28.1 \pm 0.37$ and $24.0 \pm 0.18,58.6 \pm 0.32$ and $56 \pm 0.05,65.5 \pm 0.35$ and $62.3 \pm 0.17,75.9 \pm 0.47$ and $71.0 \pm 0.21$, $16.95 \pm 0.18$ and $15.24 \pm 0.09,7.45 \pm 0.06$ and $6.5 \pm 0.03,27.44 \pm 0.3$ and $21.04 \pm 0.26,17.11 \pm 0.42$ and $9.56 \pm 0.14 \mathrm{~cm}$, respectively. Body weight and linear body measurements were higher in ram and increased with age. The correlation coefficient between body weight and most of the linear body measurement at different sex and age group were positive. The highest correlation coefficient was obtained between body weight and chest girth for both sex and age groups.
\end{abstract}

Conclusion: It was concluded that native sheep had a possible for the versatile role to generate income for livestock keepers. Therefore, genetic improvment program should aim at farmers need to cope with trait preference and existing traditional herding and breeding practice.

Keywords: Agroecology, Qualitative character, Sex, Age, Linear measurement, Correlation

\section{Background}

About 29.33 million heads of sheep population are found in Ethiopia [1]. The sheep's are widely dispersed and adapted across the different agro-ecologies of the country, out of which about $72.77 \%$ are female and about $27.23 \%$ are males. Majority of the sheep are found in the highlands, while one-fourth of them are reared in the lowlands [2]. Morphological and molecular both

*Correspondence: fhailema@gmail.com

Department of Animal Science, College of Agriculture, Aksum University Shire Campus, Tigray, Ethiopia characterizations of sheep breeds in the country are traditionally recognized by ethnic and/or geographic nomenclatures. Based on this, the sheep breeds have been classified into 14 traditional populations in 9 breeds within 6 major breed groups [3]. However, some parts of the country viz. Gambella regions and the northern part of Tigray bordering Eritrea were not considered in his study implying the possibilities of the existence of additional populations in the country.

Generally, the current state of knowledge on the characterization of farm animal generic resources in Ethiopia shows that there is still lack of information about 
the production characters of local breeds managed in their native production system [4] although the country is widely known to possess a large population of livestock with enormous diversity. Indigenous sheep genetic resources have developed specific adaptations to survive and produce under adverse condition of climatic stresses, poor quality feed, seasonal feed and water shortage, endemic disease and parasite challenge that make them suitable for their use in the traditional, low-external-input production system [5]. Therefore, selection and breeding based on zoometric/morphometrical measurement, fast growth rate, good body size and conformation [6] could result in improvement in live weight of indigenous sheep and goat for meat production $[7,8]$. The productivity of sheep as in the case of most of the ruminants is markedly low due to several genetic and environmental factors [9].

The information on body measurement is the basis for the establishment of further advanced characterization, conservation, breeding and selection strategies for indigenous sheep breed $[10,11]$ and used to assess the type and function and the value of the animal as potential breeding stocks [12]. Body measurements are wellthought-out as qualitative development indicator which reflects the conformational fluctuations occurring during the life span of animals [13].

Gamogofa zone is geographically located in Southern, Nation, Nationalities and Peoples of Regional State (SNNPRS) of Ethiopia. Even though the study area is rich in livestock resources including small ruminants, still there is a long way to go to characterize, identify and document the existing indigenous sheep type/s of the region. The overall objective of this study, therefore, was to describe the morphological of the indigenous sheep population of Gamogofa Zone based on their morphological and quantitative trait.

\section{Methods}

The study was carried out within the period October 2015 to May 2016 in four 'Woredas.' The sampling frame was established using purposive sampling to selected the four 'Woredas' based on agroecology, sheep population distribution, availability of transportation and their contribution to farmers. From each selected 'Woredas', two rural 'Kebeles' were selected based on flock size, sheep population and agroecology area. The sample size was determined according to [14], and based on this formula, the calculated sample size is 384 but, for the higher accuracy, the total number of sampling size for this study was increased to 736 . Therefore, qualitative and quantitative measurements were made on 736 (181 males and 555 non-pregnant females in the proportion of 25 males/75 females) mature sheep were selected randomly (184 per district, 92 per rural 'Kebele'). Quantitative traits including body length, pelvic width, chest width, tail length, tail circumference, head length, head width, cannon bone length and width, horn length, ear length and scrotum circumstance were measured using measuring tape, and height at wither and shoulder width were measured using self-devised scale (which is locally made from wooden material), while the body weight was measured using suspended spring balance of $50 \mathrm{~kg}$ (weighing scale). The age of the animal was estimated by recall and dentition methods. Adult sheep were classified in to five groups; no pair of permanent incisors (OPPI), one pair of permanent incisors (1PPI), two pair of permanenet incisors (2PPI), three pair of permanent incisors (3PPI) and four pair permanent incisors (4PPI) to represent age of $<15,15.5-20,22.5-27,28-36$ and above 39 months, respectively.

\section{Statistical analysis}

Quantitative characters (body weight and linear body measurements) were analyzed using the Generalized Linear Model (GLM) procedures of the Statistical Analysis System (SAS, release 9.1, 2003). For adult animals, agroecology, sex and age group were fitted as fixed independent variables, while body weight and linear body measurements (except scrotum circumference) were fitted as dependent variables. Scrotum circumference was analyzed for each type by fitting agroecology and age group as a fixed factor. Mean separation was under taken when it was significant to reveal the difference between mean using Duncan multiple range test. The model to analyze body weight and linear body measurements was:

$$
Y_{i j k}=\mu+E_{i}+A_{j}+S_{k}+(\mathrm{AS})_{j k}+e_{i j k}
$$

where $Y_{i j k}$, the observed k (body weight or linear body measurement) in the $i$ th agroecology, $j$ th age group and $k$ th sex; $\mu$, overall mean; $E_{i}$, the effect of $i$ th agroecology ( $i=$ 'Dega,' 'Wenya-dega'); $A_{j}$, the effect of $j$ th age group $(j=1,2,3$ and 4$) ; S_{k}$, the effect of $k$ th sex ( $k=$ intact ram and ewe); (AS) $)_{i}$, interaction effect of $i$ th age group with $j$ th of sex; $e_{i j k}$, random residual error.

Body weight (BW) and other linear body measurements including chest girth (CG), body length (BL), wither height $(\mathrm{WH})$, pelvic width (PW), ear length (EL), horn length (HL), tail length (TL), tail circumference (TC), head length (HL), head width (HW), shoulder width $(\mathrm{SW})$, cannon bone length $(\mathrm{CBL})$, cannon bone circumference $(\mathrm{CBC})$ and Scrotum circumference (SC) were conducted for rams, whereas scrotum circumference (SC) was excluded from the analysis of ewes sheep.

\section{Results}

\section{Qualitative character}

The physical body characterization on sheep production is presented in Table 1. Most of the sheep in the study 
Table 1 Qualitative character of sheep

\begin{tabular}{|c|c|c|c|c|c|}
\hline Trait & Class level & $\begin{array}{l}\text { Ewe } \\
N(\%)\end{array}$ & $\begin{array}{l}\text { Ram } \\
N(\%)\end{array}$ & $\begin{array}{l}\text { Overall } \\
N(\%)\end{array}$ & $x^{2}$ \\
\hline \multirow{3}{*}{$\begin{array}{c}\text { Coat color } \\
\text { pattern }\end{array}$} & Plain & $388(69.9)$ & $110(60.8)$ & $498(67.7)$ & $13.13^{* *}$ \\
\hline & Patchy & 96 (17.3) & $40(22.1)$ & $136(18.5)$ & 2.09 \\
\hline & Spotted & $71(12.8)$ & $31(17.1)$ & $102(13.9)$ & 2.15 \\
\hline \multirow{10}{*}{$\begin{array}{l}\text { Coat color } \\
\text { type }\end{array}$} & White & $61(11)$ & $18(9.9)$ & 79 (10.7) & 0.156 \\
\hline & Black & $191(34.4)$ & 59 (32.6) & $250(34)$ & 1.201 \\
\hline & Red & $101(18.2)$ & $43(23.8)$ & 144 (19.6) & 0.465 \\
\hline & Brown & $43(7.7)$ & $23(12.7)$ & $66(9)$ & $4.11^{*}$ \\
\hline & Gray & $15(2.7)$ & $3(1.7)$ & $18(2.4)$ & 0.625 \\
\hline & $\begin{array}{l}\text { White domi- } \\
\text { nant }\end{array}$ & $33(5.9)$ & $8(4.4)$ & $41(5.6)$ & 2.604 \\
\hline & $\begin{array}{l}\text { Black domi- } \\
\text { nant }\end{array}$ & $80(14.4)$ & $7(3.9)$ & $87(11.8)$ & $11.228^{* *}$ \\
\hline & $\begin{array}{l}\text { Red domi- } \\
\text { nant }\end{array}$ & $17(3.1)$ & $14(7.7)$ & $31(4.2)$ & 12.92 \\
\hline & $\begin{array}{l}\text { Brown } \\
\text { dominant }\end{array}$ & $9(1.6)$ & $4(2.2)$ & $13(1.8)$ & 1.952 \\
\hline & $\begin{array}{l}\text { Gray domi- } \\
\text { nant }\end{array}$ & $5(0.9)$ & $2(1.1)$ & $7(1.0)$ & 0.605 \\
\hline \multirow[t]{2}{*}{ Hair type } & $\begin{array}{c}\text { Short and } \\
\text { smooth }\end{array}$ & $182(32.8)$ & $52(28.7)$ & $234(31.8)$ & $82.81^{* * *}$ \\
\hline & $\begin{array}{l}\text { Long and } \\
\text { coarse }\end{array}$ & $373(67.2)$ & $129(71.3)$ & $311(68.2)$ & $82.81^{* *}$ \\
\hline \multirow{3}{*}{$\begin{array}{l}\text { Head } \\
\text { profile }\end{array}$} & Straight & 497 (89.5) & $156(96.2)$ & $653(88.7)$ & $110.47^{* *}$ \\
\hline & Concave & $31(5.6)$ & $11(6.1)$ & $42(5.7)$ & 0.061 \\
\hline & Convex & $27(4.9)$ & $14(7.7)$ & $41(5.6)$ & 2.310 \\
\hline \multirow[t]{2}{*}{ Tail type } & Long fat tail & - & $87(48.1)$ & $87(11.8)$ & - \\
\hline & $\begin{array}{l}\text { Long thin } \\
\text { tail }\end{array}$ & $555(100)$ & 94 (51.9) & 649 (88.2) & $302.5^{* *}$ \\
\hline \multirow[t]{2}{*}{ Tail form } & $\begin{array}{l}\text { Carved at } \\
\text { the tip }\end{array}$ & $16(2.9)$ & $55(30.4)$ & $71(9.6)$ & $118.46^{*}$ \\
\hline & $\begin{array}{l}\text { Straight at } \\
\text { the tip }\end{array}$ & $539(97.1)$ & $126(69.6)$ & $665(90.4)$ & $118.46^{* *}$ \\
\hline \multirow[t]{3}{*}{ Ear form } & Erect & $91(16.4)$ & $32(17.7)$ & $123(16.7)$ & 1.411 \\
\hline & Horizontal & $264(47.6)$ & $113(62.4)$ & $377(51.2)$ & $12.068^{* *}$ \\
\hline & $\begin{array}{l}\text { Semi-pen- } \\
\text { dulous }\end{array}$ & $200(36)$ & 36 (19.9) & $236(32.1)$ & $16.01^{* *}$ \\
\hline \multirow[t]{2}{*}{ Horn } & Present & $356(64.1)$ & $115(63.5)$ & $471(64)$ & 0.022 \\
\hline & Absent & 199 (35.9) & $66(36.5)$ & $265(36)$ & 0.022 \\
\hline \multirow[t]{2}{*}{ Wattle } & Present & $5(0.9)$ & & $5(0.7)$ & 1.64 \\
\hline & Absent & $550(99.1)$ & $181(100)$ & 731 (99.3) & 2.03 \\
\hline$\%$ of total & & $555(75.4)$ & $181(24.4)$ & 736 (100) & \\
\hline
\end{tabular}

$N$ number of observation

*Significant at $P<0.05$; ${ }^{*}$ significant at $P<0.01$

area were thin-tailed, and the most common type of tail in both rams and ewes was long thin-tailed (88.2\%) having different coat colors. The major coat colors were plain black (34\%), red (19.6\%) and black dominant (11.8\%). The dominant of black coat color is obvious in the cold region as the black coat helps in absorption of solar radiation thereby assisting in maintaining a body temperature of the animals. Almost all ewes (99.3\%) and rams had no wattles. Most of the sheep had a straight tail at the tip $(90.4 \%)$, while $9.6 \%$ had carved at the tip.

\section{Effect of agroecology, sex and age on body weight and linear body measurement}

Agroecology seemed to have been the highest contributing $(P<0.01)$ factors to the variation in linear body measurement (LBM) and body weight (BW) of sheep (Tables 2, 3). However, the result of Tables 2 and 3 indicates that, there is no significant $(P>0.05)$ variation in the different linear body measurement of head width (HW), shoulder width (SW), tail length (TL), and tail circumference (TC) for ewe and head width, head length, shoulder width, ear length, horn length and cannon bone length for ram. The difference in the linear body measurement and the body weight within the same sex with different agroecology might be due to the non-genetic factors (like feed quality and quantity, environmental factors, management level).

The body weight, chest girth, wither height, head length, body length and pelvic width of ewe sheep found in 'Wenya-dega' agroecology were significant $(P<0.01)$ higher than those in the 'Dega' agroecology. A similar trend was observed for body weight and linear body measurement of rams found in 'Wenya-dega' agroecology except for head length which is not significant $(P>0.05)$. The superiority in the body weight and linear body measurement of 'Wenya-dega' over 'Dega' agroecology could be a result of the difference in nutritional/feed availability, location, management level of the sheep and high population density in 'Dega' agroecology results more grazing/ feed resources shifts to crop production/cultivation.

The body weight of mature ram and ewe sheep found in 'Wenya-dega' agroecology was 29.38 and $25.13 \mathrm{~kg}$, respectively. This value is higher than the body weight of mature rams and ewes reared in the Dega areas. As shown in Tables 2 and 3, sex of the sheep had a significant $(P<0.01)$ effect on BW, WH, HW, CG, BL, SW, TL, TC, HL, CBL, and CBC. The study indicates that EL and PW were not significantly $(P>0.05)$ influenced by the sex. The difference in body weight and LBM of rams and ewes shows that these parameters are sex dependent. Scrotum circumference too increased with age and hence significantly $(P<0.01)$ differed from each other. The value of scrotum circumference obtained in the study was 22.75 , 26.16 and $31.30 \mathrm{~cm}$ for the lower-age (1PPI), middle-age (2PPI) and higher-age groups ( $\geq 3 \mathrm{PPI})$, respectively.

Body weight, chest girth, body length, wither height and shoulder width of ram sheep at one pair of teeth (1PPI) were $25.49 \mathrm{~kg}, 72.64 \mathrm{~cm}, 62.76 \mathrm{~cm} 56.90 \mathrm{~cm}$ and $14.69 \mathrm{~cm}$, respectively. The value of ewe sheep at the same age group was $20.88 \mathrm{~kg}, 67.42 \mathrm{~cm}, 59.89 \mathrm{~cm}$, 
Table 2 Least square mean and standard error $(L S M \pm S E)$ of body weight $(\mathrm{kg})$ and linear body measurement $(\mathrm{cm})$ of sheep population

\begin{tabular}{|c|c|c|c|c|c|c|c|c|}
\hline Effect & WH & HW & HL & $\mathrm{BL}$ & PW & $\mathrm{CH}$ & SW & BW \\
\hline Agroecology & $* *$ & ns & $* *$ & $* *$ & $* *$ & $* *$ & ns & $* *$ \\
\hline 'Dega' ewe & $54.9 \pm 0.17$ & $8.81 \pm 0.06$ & $15.6 \pm 0.08$ & $61.4 \pm 0.21$ & $12.9 \pm 0.10$ & $70.0 \pm 0.24$ & $15.4 \pm 0.10$ & $22.9 \pm 0.22$ \\
\hline \multirow[t]{2}{*}{ WD ewe } & $57 \pm 0.23$ & $8.89 \pm 0.08$ & $16.4 \pm 0.06$ & $63.5 \pm 0.25$ & $14.6 \pm 0.08$ & $71.9 \pm 0.34$ & $15.1 \pm 0.14$ & $25.1 \pm 0.28$ \\
\hline & $* *$ & ns & ns & $* *$ & $* *$ & $* *$ & ns & $* *$ \\
\hline 'Dega'ram & $57.5 \pm 0.49$ & $9.80 \pm 0.13$ & $17.2 \pm 0.14$ & $64.4 \pm 0.51$ & $12.6 \pm 0.21$ & $74.9 \pm 0.73$ & $17.07 \pm 0.30$ & $26.7 \pm 0.63$ \\
\hline WD ram & $59.8 \pm 0.40$ & $10.1 \pm 0.12$ & $16.9 \pm 0.13$ & $66.6 \pm 0.45$ & $14.5 \pm 0.13$ & $76.8 \pm 0.60$ & $16.82 \pm 0.22$ & $29.4 \pm 0.43$ \\
\hline Sex & $* *$ & $* *$ & $* *$ & $* *$ & ns & $* *$ & $* *$ & $* *$ \\
\hline Ram & $58.6 \pm 0.32$ & $9.92 \pm 0.09^{a}$ & $17.1 \pm 0.10$ & $65.5 \pm 0.35$ & $13.6 \pm 0.1$ & $75.9 \pm 0.47$ & $16.95 \pm 0.18$ & $28.1 \pm 0.37$ \\
\hline Ewe & $56.0 \pm 0.15$ & $8.80 \pm 0.05^{b}$ & $16.0 \pm 0.05$ & $62.3 \pm 0.17$ & $13.8 \pm 0.1$ & $71.0 \pm 0.21$ & $15.24 \pm 0.09$ & $24.0 \pm 0.18$ \\
\hline Age & $* *$ & $*$ & $* *$ & $* *$ & $* *$ & $* *$ & $* *$ & $* *$ \\
\hline $1 \mathrm{PPI}$ & $54.9 \pm 0.23^{\mathrm{a}}$ & $8.77 \pm 0.07^{a}$ & $15.64 \pm 0.09^{\mathrm{a}}$ & $60.96 \pm 0.35^{\mathrm{a}}$ & $12.4 \pm 0.08^{\mathrm{a}}$ & $69.4 \pm 0.38^{\mathrm{a}}$ & $14.8 \pm 0.12^{\mathrm{a}}$ & $23.5 \pm 0.27^{a}$ \\
\hline $2 \mathrm{PPI}$ & $57.5 \pm 0.24^{b}$ & $8.98 \pm 0.08^{b}$ & $16.32 \pm 0.08^{b}$ & $63 \pm 0.29^{b}$ & $13.4 \pm 0.10^{b}$ & $74.0 \pm 0.41^{b}$ & $15.5 \pm 0.16^{b}$ & $25.9 \pm 0.31^{b}$ \\
\hline$\geq 3 \mathrm{PPI}$ & $59.2 \pm 0.22^{c}$ & $9.48 \pm 0.08^{b}$ & $16.70 \pm 0.07^{b}$ & $65.87 \pm 0.24^{c}$ & $15.0 \pm 0.07^{c}$ & $76.6 \pm 0.33^{c}$ & $18.0 \pm 0.13^{c}$ & $28.9 \pm 0.27^{c}$ \\
\hline Sexbyage & $* *$ & ns & ns & * & ns & $* *$ & $* *$ & $* *$ \\
\hline Ewe*1PPI & $53.7 \pm 0.21^{\mathrm{a}}$ & $8.32 \pm 0.07$ & $15.1 \pm 0.09$ & $59.9 \pm 0.27^{\mathrm{a}}$ & $12.1 \pm 0.09$ & $67.2 \pm 0.41^{\mathrm{a}}$ & $14.2 \pm 0.13^{\mathrm{a}}$ & $20.9 \pm 0.25^{\mathrm{a}}$ \\
\hline Ewe*2PPI & $55.7 \pm 0.23^{b}$ & $8.72 \pm 0.09$ & $16.1 \pm 0.09$ & $62.9 \pm 0.29^{b c}$ & $13.2 \pm 0.11$ & $70.2 \pm 0.38^{b}$ & $14.9 \pm 0.15^{b}$ & $23.6 \pm 0.28^{b}$ \\
\hline $\mathrm{Ewe}^{*} \geq 3 \mathrm{PPI}$ & $57.4 \pm 0.22^{c}$ & $9.22 \pm 0.07$ & $17.5 \pm 0.07$ & $64.0 \pm 0.23 c$ & $14.9 \pm 0.08$ & $73.4 \pm 0.32^{c}$ & $16.0 \pm 0.13^{c}$ & $26.0 \pm 0.26^{c}$ \\
\hline Ram*1PPI & $56.9 \pm 0.43^{b c}$ & $9.53 \pm 0.10$ & $16.5 \pm 0.14$ & $62.8 \pm 0.79^{b}$ & $12.8 \pm 0.16$ & $72.6 \pm 0.62^{c}$ & $14.7 \pm 0.21^{b}$ & $25.5 \pm 0.44^{c}$ \\
\hline $\operatorname{Ram}^{*} 2 \mathrm{PPI}$ & $59.2 \pm 0.54^{d}$ & $9.99 \pm 0.16$ & $17.1 \pm 0.18$ & $65.5 \pm 0.51^{\mathrm{cd}}$ & $13.6 \pm 0.24$ & $76.9 \pm 0.69^{d}$ & $17.5 \pm 0.31^{c}$ & $28.6 \pm 0.59^{d}$ \\
\hline $\operatorname{Ram}^{*} \geq 3 \mathrm{PPI}$ & $60.4 \pm 0.38^{d}$ & $10.9 \pm 0.16$ & $17.8 \pm 0.15$ & $68.4 \pm 0.54^{e}$ & $15.4 \pm 0.21$ & $80.0 \pm 0.58^{e}$ & $18.8 \pm 0.29^{e}$ & $31.6 \pm 0.55^{e}$ \\
\hline
\end{tabular}

WD'Wenya-dega', $W H$ wither height, $H W$ head width, $H L$ head length, $B L$ body length, $P W$ pelvic width, $C G$ chest girth, SW shoulder width, $B W$ body weight,

$1 P P I$ one pair of permanent teeth, $2 P P I$ two pair of permanent teeth, $\geq 3 P P I \geq$ three pair of permanent teeth, ns nonsignificant

$a, b, c, d$ means with different superscripts across column are significantly different

**Significant at $(P<0.01)$, *significant at $(P<0.05)$

$53.70 \mathrm{~cm}$ and $14.21 \mathrm{~cm}$, respectively. The measurement for the higher-age group ( $\geq 3 \mathrm{PPI})$ was $31.62 \mathrm{~kg}, 80 \mathrm{~cm}$, $68.43 \mathrm{~cm}, 60.40 \mathrm{~cm}$ and $18.78 \mathrm{~cm}$ for ram, respectively, and the values of ewe sheep at the same age group were $25.97 \mathrm{~kg}, 73.44 \mathrm{~cm}, 64.04 \mathrm{~cm}, 57.40 \mathrm{~cm}$ and $16.03 \mathrm{~cm}$, respectively. CBL, CBW and PW of ram sheep at one pair of teeth were $12.66,7.12$ and $12.78 \mathrm{~cm}$, respectively, and the value of ewe at the same age group was $11.99,6.26$ and $12.14 \mathrm{~cm}$, respectively.

\section{Correlation}

The phenotypic correlation coefficients between body weight and linear body measurements within age group and sex are presented in Table 4. The result of the study indicates that $\mathrm{WH}, \mathrm{HW}, \mathrm{BL}, \mathrm{CG}, \mathrm{SW}, \mathrm{CBL}, \mathrm{CBW}$ and TC were significantly $(P<0.01)$ correlated with $\mathrm{BW}$ at all of the age groups and in both of the sexes, while SC was also observed to be significantly $(P<0.01)$ correlated with the BW of the rams. The results further indicate that horn length $(\mathrm{HOL})$ was significantly $(P<0.01)$ correlated with $\mathrm{BW}$ in ram at $1 \mathrm{PPI}$ age groups and ewes at 2 PPI and $\geq 3$ PPI age group, while it was also significantly $(P<0.05)$ correlated with $\mathrm{BW}$ in ewe at the 1PPI age group. The results for the correlations between TL and BW indicate that it is significantly $(P<0.01)$ correlated with rams at 1 PPI and 2PPI. It is also significantly $(P<0.05)$ correlated for rams at $\geq 3$ PPI age group. However, still, it is negative but significant $(P<0.01)$ for ewes at all age groups. The correlation values between TC and $\mathrm{BW}$ indicate that they were significantly $(P<0.05)$ correlated with the rams at 2PPI age group, while they were significantly $(P<0.01)$ correlated for all age groups and both sexes.

\section{Discussion}

The difference of linear body measurement and body weight within the same sex with different agroecology might be due to the non-genetic factors and also location. However, the result obtained in the present study was in consonance with the observation of Belete et al. [15], and Kunene et al. [16] indicated that location was the highest contributing factor for the variation of linear body measurement and body weight of animals.

The superiority in the body weight and linear body measurement of 'Wenya-dega' over 'Dega' agroecology could be a result of the difference in nutritional, location and management level of the sheep. The obtained result is in consonance with the result of Oke and Ogbonnaya 
Table 3 Least square mean and standard error (LSM \pm SE) of linear body measurement $(\mathrm{cm})$ sheep breed

\begin{tabular}{|c|c|c|c|c|c|c|c|}
\hline Effect & $\mathrm{EL}$ & CBL & CBW & $\mathrm{TL}$ & $\mathrm{TC}$ & HOL & $\mathrm{SC}$ \\
\hline Agroecology & $*$ & * & $*$ & $\mathrm{~ns}$ & $\mathrm{~ns}$ & $\mathrm{~ns}$ & na \\
\hline 'Dega' ewe & $8.62 \pm 0.15$ & $12.5 \pm 0.07$ & $6.44 \pm 0.03$ & $21.4 \pm 0.37$ & $9.69 \pm 0.19$ & $6.34 \pm 0.15$ & \\
\hline \multirow[t]{2}{*}{ WD ewe } & $9.72 \pm 0.16$ & $12.8 \pm 0.08$ & $6.57 \pm 0.05$ & $20.7 \pm 0.37$ & $9.42 \pm 0.21$ & $7.09 \pm 0.16$ & \\
\hline & ns & ns & $* *$ & $* *$ & $* *$ & ns & $*$ \\
\hline 'Dega'ram & $8.46 \pm 0.19$ & $13.27 \pm 0.19$ & $7.19 \pm 0.09$ & $26.41 \pm 0.37$ & $15.07 \pm 0.62$ & $20.5 \pm 0.86$ & $25.4 \pm 0.73$ \\
\hline WD ram & $8.82 \pm 0.14$ & $13.64 \pm 0.14$ & $7.72 \pm 0.08$ & $28.46 \pm 0.41$ & $19.16 \pm 0.49$ & $20.3 \pm 1.42$ & $28.1 \pm 0.59$ \\
\hline $\operatorname{sex}$ & ns & $* *$ & $* *$ & $* *$ & $* *$ & $* *$ & na \\
\hline Ewe & $9.03+0.09$ & $12.67+0.05$ & $6.50+0.03$ & $21.04 \pm 0.26$ & $9.56 \pm 0.14$ & $6.72 \pm 0.11$ & \\
\hline Ram & $8.68 \pm 0.11$ & $13.49 \pm 0.11$ & $7.45 \pm 0.06$ & $27.44 \pm 0.30$ & $17.11 \pm 0.42$ & $20.4 \pm 0.76$ & \\
\hline Age & ns & $* *$ & $* *$ & ns & * & $\mathrm{ns}$ & $* *$ \\
\hline $1 \mathrm{PPI}$ & $8.74 \pm 0.12$ & $12.2 \pm 0.07^{\mathrm{a}}$ & $6.58 \pm 0.05^{\mathrm{a}}$ & $23.2 \pm 0.41$ & $12 \pm 0.31^{\mathrm{a}}$ & $12.8 \pm 0.64$ & $22.8 \pm 0.42^{a}$ \\
\hline 2PPI & $8.82 \pm 0.14$ & $13.8 \pm 0.09^{b}$ & $6.70 \pm 0.06^{b}$ & $24.6 \pm 0.44$ & $13.7 \pm 0.38^{b}$ & $13.6 \pm 0.38$ & $26.2 \pm 0.57^{b}$ \\
\hline$\geq 3 \mathrm{PPI}$ & $9.18 \pm 0.12$ & $14.4 \pm 0.08^{c}$ & $6.91 \pm 0.05^{c}$ & $26.3 \pm 0.37$ & $14.1 \pm 0.31^{b}$ & $14.0 \pm 0.43$ & $31.3 \pm 0.63^{c}$ \\
\hline Sexbyage & ns & $* *$ & $* *$ & ns & $* *$ & & \\
\hline Ewe*1PPI & $8.90 \pm 0.16$ & $11.9 \pm 0.09^{a}$ & $6.26 \pm 0.04^{a}$ & $21 \pm 0.53$ & $8.4 \pm 0.27^{a}$ & & \\
\hline Ewe $^{*} 2 \mathrm{PPI}$ & $8.85 \pm 0.17$ & $12.6 \pm 0.08^{b}$ & $6.43 \pm 0.05^{\mathrm{a}}$ & $21.3 \pm 0.48$ & $9.3 \pm 0.26^{a}$ & & \\
\hline Ewe $^{*} \geq 3 \mathrm{PPI}$ & $9.22 \pm 0.13$ & $13.1 \pm 0.08^{b c}$ & $6.68 . \pm 0.05^{b}$ & $22.0 \pm 0.38$ & $10.5 \pm 0.21^{b}$ & & \\
\hline $\operatorname{Ram}^{*} 1 \mathrm{PPI}$ & $8.49 \pm 0.15$ & $12.7 \pm 0.12^{b}$ & $7.12 \pm 0.07^{c}$ & $26.9 \pm 0.40$ & $15.3 \pm 0.53^{c}$ & & \\
\hline $\operatorname{Ram}^{*} 2 \mathrm{PPI}$ & $8.72 \pm 0.24$ & $13.7 \pm 0.21^{c}$ & $7.60 \pm 0.12^{c}$ & $27.3 \pm 0.66$ & $17.6 \pm 0.84^{d}$ & & \\
\hline $\operatorname{Ram}^{*} \geq 3 \mathrm{PPI}$ & $9.01 \pm 0.25$ & $14.9 \pm 0.18^{d}$ & $8.16 \pm 0.11^{d}$ & $29.4 \pm 0.51$ & $20.1 \pm 0.85^{e}$ & & \\
\hline
\end{tabular}

WD'Wenya-dega', EL ear length, $C B L$ cannon bone length, $C B W$ cannon bone width, $T L$ tail length, $T C$ tail circumference, $H O L$ horn length, $S C$ scrotum circumference, $1 P P I$ one pair of permanent teeth, $2 P P I$ two pair of permanent teeth, $\geq 3 P P I \geq$ three pair of permanent teeth, na not applicable, ns nonsignificant

$\mathrm{a}, \mathrm{b}, \mathrm{c}, \mathrm{d}$ means with different superscripts across column are significantly different

**Significant at $(P<0.01)$, ${ }^{*}$ significant at $(P<0.05)$

Table 4 Phenotypic correlation between body weight and linear body measurement of sheep breed within sex and age group

\begin{tabular}{|c|c|c|c|c|c|c|}
\hline \multirow[t]{2}{*}{ Traits } & \multicolumn{2}{|l|}{ 1PPI } & \multicolumn{2}{|l|}{$2 \mathrm{PPI}$} & \multicolumn{2}{|l|}{$\geq 3 \mathrm{PPI}$} \\
\hline & Ram & Ewe & Ram & Ewe & Ram & Ewe \\
\hline WH & $0.762^{* *}$ & $0.717^{* *}$ & $0.758^{* *}$ & $0.634^{* *}$ & $0.620^{* *}$ & $0.566^{* *}$ \\
\hline $\mathrm{HOL}$ & $0.533^{* *}$ & $0.228^{*}$ & 0.063 & $0.314^{* *}$ & 0.017 & $0.305^{* *}$ \\
\hline EL & 0.085 & 0.093 & 0.109 & 0.047 & 0.053 & 0.112 \\
\hline HW & $0.634^{* *}$ & $0.428^{* *}$ & $0.527^{* *}$ & $0.449^{* *}$ & $0.570^{* *}$ & $0.569^{* *}$ \\
\hline $\mathrm{HL}$ & $0.465^{* *}$ & $0.132^{\mathrm{ns}}$ & $0.241^{*}$ & $0.349^{* *}$ & $0.310^{*}$ & $0.429^{* *}$ \\
\hline$B L$ & $0.833^{* *}$ & $0.799^{* *}$ & $0.716^{* *}$ & $0.771^{* *}$ & $0.664^{* *}$ & $0.707^{* *}$ \\
\hline PW & $0.668^{* *}$ & $0.563^{* *}$ & $0.683^{* *}$ & $0.442^{* *}$ & $0.617^{* *}$ & $0.439^{* *}$ \\
\hline$C G$ & $0.921^{* *}$ & $0.841^{* *}$ & $0.826^{* *}$ & $0.805^{* *}$ & $0.925^{* *}$ & $0.832^{* *}$ \\
\hline SW & $0.575^{* *}$ & $0.379^{* *}$ & $0.526^{* *}$ & $0.459^{* *}$ & $0.530^{* *}$ & $0.509^{* *}$ \\
\hline CBL & $0.674^{* *}$ & $0.590^{* *}$ & $0.705^{* *}$ & $0.454^{* *}$ & $0.545^{* *}$ & $0.569^{* *}$ \\
\hline CBW & $0.624^{* *}$ & $0.632^{* *}$ & $0.620^{* *}$ & $0.605^{* *}$ & $0.600^{* *}$ & $0.635^{* *}$ \\
\hline$T L$ & $0.410^{* *}$ & $-0.300^{* *}$ & $0.400^{* *}$ & $-0.298^{* *}$ & $0.337^{*}$ & $-0.347^{* *}$ \\
\hline TC & $0.483^{* *}$ & $0.436^{* *}$ & $0.355^{*}$ & $0.405^{* *}$ & $0.481^{* *}$ & $0.508^{* *}$ \\
\hline SC & $0.715^{* *}$ & - & $0.547^{* *}$ & - & $0.627^{* *}$ & - \\
\hline
\end{tabular}

WH wither height, $H O L$ horn length, $E L$ ear length, $H W$ head width, $H L$ head length, $B L$ body length, $P W$ pelvic width, $C G$ chest girth, SW shoulder width, $C B L$ cannon bone length, $C B W$ cannon bone width, $T L$ tail length, $T C$ tail circumference, SC scrotum circumference, $1 P P I$ one pair of permanent teeth, $2 P P I$ two pair of permanent teeth, $\geq 3 P P I \geq$ three pair of permanent teeth, $n s$ nonsignificant

**Significant at $P<0.01,{ }^{*}$ significant at $P<0.05$ 
[10] and Mengistie et al. [17], and the variation in linear body measurement (LBM) was influenced by the location where an animal was raised and by its age [16]. In contrary to this result, Legaze et al. [18] reported that location effect showed a very low significance in the morphological traits, leaving a more important influence on the flocking effect nested into the location effect.

The body weight of mature ram and ewe sheep found in 'Wenya-dega' agroecology was 29.38 and $25.13 \mathrm{~kg}$, respectively. This result is in line with the body weight of afar and Menz sheep breed [19]. Birhan and Aynealem [20] reported a wide variation in growth performance between districts could be an advantage to improve the genetic potentials of local sheep with a long-term selection effort. Scrotum circumference of rams for 'Wenyadega' agroecology was wider than for 'Dega' rams. This may be due to existing of the nutritional level of the feed. According to the report of Nugussie et al. [21], feeding high quality and quantity of feed could enhance testicular growth as the indicator of the scrotum circumference.

Body weight of mature ewe flocks found in this study is comparable to the reports from in Bensa district of southern Ethiopia and Sub-Saharan Africa [22, 23]. The effect of sex on body weight, chest girth, pelvic width and wither height obtained in this study is comparable to the value of Bonga, Abergelle, Washera and Gumuz sheep breed [13, 17, 24, 25]. The average value of body length $(65.49 \mathrm{~cm}$ ram and $62.43 \mathrm{~cm}$ ewe) obtained in the study was higher than the average body length of central highland sheep, Afar and Menz sheep breed [13, 19] and Washera sheep of western highland sheep [17]. The average value of chest girth both for the rams $(75.86 \mathrm{~cm})$ and ewes $(70.98 \mathrm{~cm})$ was also comparable to the average value of Abergelle sheep breed [13].

Body weight and body measurements of body length and chest girth obtained in this study are comparable with the previous report on Washera sheep under traditional management system [17] but higher than the sheep type found in Bale zone [15]. Body weight obtained at the higher-age group of ewes and rams in the in the study is comparable with the on-farm study by Tesfaye [19] for Afar ewes and rams and higher than Menz ewes and rams. Body weight and body measurement of mature sheep in the present study are higher than values reported for Abergelle sheep breed under the traditional management of Northern Tigray [26] but lower than Gumuz sheep breed [25]. Similarly, the chest girth obtained at the lower-age group (1PPI) in the present study was higher than the chest girth for Menz and Horro sheep at 365 days [27].

The head width and shoulder width obtained in this study were lower than Yakassa and Balami sheep breed of Nigeria [11] and longer head length and wider head width for West Africa dwarf sheep [7].

Pelvic width at the oldest age group obtained in this study is comparable with the result of Mengistie et al. [17], and the relatively lower body weight for both ram and ewes recorded in the current study than by Adilo for ewe, Bonga, Horro and Gumuz [24, 28] might be attributed to the difference in the level of management, genetic factor and related to the location effect.

The average value of tail length for mature ewes and rams obtained in the study was lower than the average value of Gumuz and Washera ewe and rams with an onfarm management $[25,29]$ and longer than Afar ewe and rams [19].

The observations pertaining to the correlations between linear measurements and BW have also been more or less documented [10, 19, 25, 29]. The moderate to high correlation coefficients between body weight and linear body measurements for all age groups suggest that either of these variables or their combination could provide a better evaluation for forecasting live weight of sheep.

\section{Conclusion}

Gamogofa sheep population is a multicolored breed and identified as thin-tailed with the straight tail form at the tip. Agroecology, sex and age group had a significant $(P<0.01)$ effect on body weight and linear body measurement. The body weight of rams and ewes in 'Wenyadega' were higher when compared to the body weight of ram and ewes of 'Dega' agroecology, respectively. Generally, positive and significant $(P<0.01)$ correlation was obtained between the body weight and most of the linear body measurement. Therefore, it strongly recommended that further genetic analyses should be used to determine the genetic variation between and within these small populations to develop an effective conservation and utilization program.

\section{Authors' contributions}

$\mathrm{FH}$ is the principal researcher, prepared interview schedule to collect data, analysis and prepared this manuscript. DG and HH have guided FH while undertaking this research from the very beginning of the study. They helped for FH in data entry, analysis, revised manuscript minutely with critical comments and suggestions and drafted the manuscript. All authors read and approved the final manuscript.

\section{Acknowledgements \\ Authors sincere thanks to the SARI for the reliable budget support and Gamogofa zone Agricultural and Rural Development Office of southern Ethiopia for giving us the chance and allowing us to support for selecting high sheep population density.}

\section{Competing interests}

The authors declare that they have no competing interests. 


\section{Availability of data and materials}

The datasets used and analyzed during the current study are available from the first author on reasonable request.

\section{Consent for publication}

All data and information are generated from the main authors, and verbal informed consent was received to collect data and for publication during data collection.

\section{Ethics approval and consent to participate}

Not applicable.

\section{Funding}

This study was financially supported by SARI.

\section{Significance statements}

This study will help the researcher to uncover the critical area of phenotypic characterization in sheep population that many researchers were not able to explore. This study discovers the effect of agroecology, sex and age on body weight and linear body measurements. These value used as reference in the future studies on the genetic characterization and improvement through conservation of the breeds.

\section{Publisher's Note}

Springer Nature remains neutral with regard to jurisdictional claims in published maps and institutional affiliations.

Received: 4 October 2017 Accepted: 21 March 2018

Published online: 03 April 2018

\section{References}

1. CSA (Ethiopia Central Statistical Agency). Agricultural Sample Survey. The National Statistics. Report on livestock and livestock characteristic in Addis Ababa, Ethiopia. February, 2015; vol. II.

2. Assen $E_{1}$ Aklilu $H$. Sheep and goat production and utilization in different agro-ecological zones in Tigray, Ethiopia. Liv Res Rur Dev. 2012;24(1):16.

3. Solomon G. Sheep resource of Ethiopia: genetic diversity and breeding strategy. Ph.D. thesis, Wageningen University, the Netherlands. 2008; P. 47-97.

4. Workneh A, Ephrem G, Markos T, Yetnayet M, Rege JEO. Current status of knowledge on the characterization of farm animal genetic resources in Ethiopia. In: Proceeding of the 11th annual conference of Ethiopia Society of Animal Production (ESAP). 28-30 August, Addis Ababa, Ethiopia. 2004; p. 1-21.

5. IBC (Institute of Biodiversity Conservation). The State of Ethiopia's Farm Animal Genetic Resources: Country Report. A Contribution to the First Report on the State of the World's Animal Genetic Resources, Addis Ababa, Ethiopia. 2004.

6. Zewdu E, Aynalem H, Markos T, Sharma AK, Sölkner J, Wurzinger M. Breeding practices of indigenous sheep breeds of smallholders for designing community based-breeding strategies in Ethiopia. In: Proceedings of the 16th annual conference of the Ethiopian Society of Animal Production (ESAP), 8-10 October, Addis Ababa, Ethiopia. 2009; P. 241-6.

7. Sowande OS, Sobola OS. Body measurements of West African dwarf sheep as parameters for estimation of live weight. Trop Anim Health Prod. 2008:40:433.

8. Sowande OS, Oyewale BF, lyasere OS. Age- and sex-dependent regression models for predicting the live weight of West African Dwarf goat from body measurements. Trop Anim Health Prod. 2010;42:969-75.

9. Markos T. Productivity and health of indigenous sheep breeds and crossbred in the central highland of Ethiopia. Ph.D. dissertation. Swedish University of Agricultural Sciences, Uppsal, Sweden. 2006; P. 89.

10. Oke UK, Ogbonnaya EO. Application of physical body traits in the assessment of breed and performance of WAD sheep in a humid tropical environment. Liv Res Rur Dev. 2011;23(2):24.
11. Ibrahim Yakubu A, Isa A. Multivariate analysis of morpho-structural characteristics in Nigerian indigenous sheep. Ital J Anim Sci. 2011;10:e17.

12. Aamir HM, Babiker SA, Youssif GM, Hassan YA. Phenotypic characterization of Sudanese Kenana cattle. Res J Anim Vet Sci. 2010;5:43-7.

13. Sisay L. Phenotypic characterization of indigenous sheep breeds in the Amhara National Regional State of Ethiopia. Master thesis, Haramaya University, Haramaya, Ethiopia. 2009; P. 87-102.

14. Thrusfield MV. Veterinary epidemiology. 3rd ed. Edinburgh: Black Wellsience Ltd.; 2007. p. 229-50.

15. Belete A, Tadesse A, Eshetu A. Phenotypic characterization of indigenous sheep types in Bale Zone, Oromia Regional State, Ethiopia. J Vet Sci Technol. 2017;8:4.

16. Kunene NW, Nesamvuni EA, Fossey A. Characterization of Zulu (Nguni) sheep using linear body measurements and some environmental factors affecting these measurements. S Afr J Anim Sci. 2007;37(1):11-20.

17. Mengistie T, Girma A, Solomon G, Sisay L, Abebe M, Tibbo M. Traditional management systems and linear body measurements of Washera sheep in the western highlands of the Amhara National Regional State, Ethiopia. Liv Res Rural Dev. 2010;22(9):169.

18. Legaze E, Cervantes I, Pérez-Cabal MA, Fuente LF, Mártinez R, Goyachee F, Gutiérrez JP. Multivariate characterization of morphological traits in Assaf Sheep. Small Rum Res. 2011;100(2-3):122-30.

19. Tesfaye G. Characterization of Menz and Afar indigenous sheep breeds of smallholders and pastoralists for designing community-based breeding strategies in Ethiopia. Master of thesis; Haramaya University, Ethiopia. 2008; P. 52-76.

20. Berhanu B, Aynalem H. Reproductive performance of traditionally managed sheep in the south western part of Ethiopia. Liv Res Rur Dev. 2009;21:154.

21. Nugussie D, Shenkoru T, Tegegne A. Growth rates and testicular characteristics of Ethiopian highland sheep offered chickpea haulm supplemented with incremental levels of Leucaena leucocephala leaf hay. Liv Prod Sci. 2000:65:209-17.

22. Hizkel K, Yoseph M, Yosef T. On farm phenotypic characterization of indigenous sheep type in Bensa District, Southern Ethiopia. J Bio Agric Health. 2017;7:224-3208

23. FAO (Food and Agriculture Organization of the United Nations). Cattle and small ruminant production systems in sub-Saharan Africa - a systematic review. In: Otte MJ, Chilonda P, editors. Livestock information sector analysis and policy branch. Rome: FAO; 2000.

24. Zewdu E. Characterization of Bonga and Horro indigenous sheep breeds of smallholders for designing community-based breeding strategies in Ethiopia. Master thesis, Haramaya University, Haramaya, Ethiopia. 2008; P. 106.

25. Solomon A, Hegde BP, Mengistie T. Growth and physical body characteristics of Gumuz sheep under traditional management systems in Amhara Regional State, Ethiopia. Liv Res Rur Dev. 2011;23(5):117.

26. Tajebe S, Gangwar SK, Kefelegn K. Performance and physical body measurement of Abergell sheep breed under traditional management system of Tigray Regional State, Northern Ethiopia. Int J Sci Nat. 2011;2(2):225-30.

27. Kassahun A. Comparative performance evaluation of Horro and Menz sheep of Ethiopia under grazing and intensive feeding condition. Ph.D. dissertation, Humboldt-University. 2000; P. 129

28. Solomon G, Komen H, Hanotte O, Van Arendonk JAM. Indigenous sheep resources of Ethiopia: types, production systems, and farmer's preferences. Anim Genet Resour Inf. 2008;43:25-39.

29. Mengistie T, Girma A, Sisay L, Solomon G, Abebe M, Marikos T. Reproductive performance and survival of Washera sheep under traditional management system at Yilmanadensa and Quarit district of the Amhara National Reginal State of Ethiopia. J Anim Vet Adv. 2011;10(9):1158-65. 